\title{
GUTTING THE GORDIAN KNOT: THE AMENDING PROCESS IN CANADA
}

\author{
W. H. MCCONNELL*
}

\section{INTRODUCTION}

According to Machiavelli: "There is nothing more difficult to arrange, more doubtful of success, and more dangerous," than making changes in a country's constitution. ${ }^{1}$ The foresight of the sixteenth-century Florentine theorist of statecraft was once more demonstrated as nine English-speaking premiers and Canadian Prime Minister Pierre-Elliott Trudeau reached a jagged accommodation on November 5, 1981, patriating the Canadian Constitution with an amending formula and rights charter after more than a year of bitter controversy. ${ }^{2}$

No sooner was the November Fifth Accord concluded than spokesmen for the predominantly French-speaking Province of Quebec, as well as for the women's and the native groups, who were not consulted and did not concur with the ultimate accommodation, severely criticized the result. ${ }^{3}$ As part of the compromise, a "legislative supremacy" clause was inserted in section 33 of the Charter of Rights and Freedoms (the Charter) enabling either Parliament or the provinces to override in their respective laws the guarantee against discrimination based on sex and other "equality" rights in section 15 (as well as "fundamental freedoms" in section 2 and "legal rights" in sections 7 to 14). For several days in November, the proposed guarantee in section 35 of aboriginal rights for Indians, Métis and Inuit was removed entirely, largely at the insistence of Alberta's Premier Lougheed who saw native land claims as conflicting with mineral development in a province which was experiencing a resource boom. After strong nationwide protest by the affected groups and their allies, the threat to have the legislative supremacy clause, applicable to sections 2 and 7 to 15, also apply to the guarantee of male and female equality in section 28 was successfully countered and the aboriginal peoples managed to have section 35 restored. ${ }^{4}$ Even so, they regarded the restoration as a doubtful victory because of the vagueness of the guarantee. Some Indians called

Copyright (C) 1981 by Law and Contemporary Problems

*Professor of Law, University of Saskatchewan

1. Anderson, Those War Wounds Acting Up Again, Macleans, Nov. 9, 1981, at 34.

2. See Anderson, Cement for a Nation, Macleans, Nov. 16, 1981, at 29.

3. Thomas, The Dangerous Solitude of Rene Levesque, MAClEANS, Nov. 16, 1981, at 33; The Globe and Mail (Toronto), Nov. 19, 1981, at 1, col. 2. See the revised text of the Constitution Act, reprinted in The Globe and Mail (Toronto), Nov. 19, 1981, at 12, col. 1.

4. See The Globe and Mail (Toronto), Nov. 24, 1981, at 1, col. 3. 
for the resignation of federal Deputy Indian Affairs Minister Paul Tellier, who was said to be quietly assuring British parliamentarians that native rights would be adequately protected by the relevant clause. ${ }^{5}$ This issue has been a continuing concern at Westminster because many of the original treaties were concluded between Canadian Indian bands and the British Crown.

As the nine premiers and the Prime Minister each made major reciprocal concessions, the isolation of Quebec's separatist Premier Réne Levésque, the only First Minister not to sign the November Fifth Accord, raised the question of whether there could be a genuine constitutional renewal in Canada in which his large, populous and culturally distinctive province did not participate. Federal Liberal governments, in power for thirty-eight of the last fifty years, had repeatedly emphasized the bilingual and bicultural (but never binational) character of the country, ${ }^{6}$ but appeared to be resigned to an accommodation with the Englishspeaking provinces. However, the political spokesmen for Quebec, where the vast majority of French-speaking Canadians resided, fervently denounced this arrangement.

Because the ultimate accommodation significantly diverges from both Trudeau's and the premiers' earlier proposals, the dispute will be examined chronologically. After a review of some of the historical and attitudinal factors involved in the controversy, the main features of the disagreement arising from the October 1980 First Ministers' Conference and the November 1981 resolution will be surveyed in sequence.

It is sufficient to state here that the chief components of the final consensus, in addition to agreement on patriation, were:

(1) the acceptance by Trudeau of the premiers' preferred amending formula ${ }^{7}$ which allowed future amendments to be made by Parliament and at least seven out of ten provinces having 50 percent of the country's population. According to section 40 , up to three nonconcurring provinces would have the privilege of opting out of an amendment by legislative resolution, in defined circumstances, but without fiscal compensation except in the areas of education and culture. Elements of Trudeau's earlier amending proposal that were dropped were a "popular referendum" device to break deadlocks under his superseded "Victoria" formula, and a veto provision for the large and more densely populated provinces of Ontario and Quebec, also under that formula. ${ }^{8}$

(2) the acceptance by the premiers of Trudeau's Charter, but with a legislative supremacy clause enabling either Parliament or the provincial legislatures to override "fundamental freedoms," "legal rights" or "equality rights." The legislative supremacy clause, however, is subject to a "sunset" provision requiring reenactment of the clause by the relevant legislative body at five-year intervals. ${ }^{9}$

\footnotetext{
5. The Star-Phoenix (Saskatoon), Nov. 28, 1981, at 3, col. 6 .

6. See the discussion of the "equal partnership between the two founding races" as the "dominating idea" of the 1963 report, in Royal Commission ON Bilingualism And Biculturalism, Preliminary REPORT 21 (1965).

7. See the revised text of the Constitution Act, supro note $3, \S \S 37-47$.

8. See The Globe and Mail (Toronto), Feb. 14, 1981, at 12, col. 1 .

9. See the revised text of the Constitution Act, supra note $3, \S 33(3)$.
} 
(3) the acceptance, at Prime Minister Trudeau's insistence, of minority language educational rights, involving access to French-language primary and secondary education for Francophones outside Quebec, and similar rights for Anglophones in Quebec "where numbers warrant."10 This provision is particularly vexing to Quebec, which had not agreed to it, and which considered it central to existing provincial jurisdiction under section 93 of the British North America Act.

\section{II}

\section{The Historical BaCkground}

While the Confederate and Union armies were fighting the final battles of the Civil War, members of the Parliament of Canada were meeting in Quebec City to debate the federation of the British North American provinces. The record of the February 1865 parliamentary debates covers more than a thousand closely printed pages, but there is little or no reference in the debates to an amending formula. ${ }^{11}$ The mechanics of such a formula do not even appear to have been discussed.

The Civil War, however, was to have a deep influence on the Canadian Constitution by prompting its framers to design a more centralized version of federalism, with a central veto power over any provincial law, and a residuary clause, unlike that in the tenth amendment to the United States Constitution, assigning any unallocated subject matters to the central government. ${ }^{12}$ But the absence of a domestic amending formula meant that when future amendments were sought, the Canadian Parliament would be obliged to present a Joint Address to the Queen ${ }^{13}$ asking her to have the United Kingdom Parliament amend the written portion of the Canadian Constitution which was set out in a British statute. ${ }^{14}$

Certain parts of the British North America Act (B.N.A. Act), for example section 41 relating to federal elections, or section $92(1)$ relating to provincial constitutions, were made amendable by the appropriate legislatures from the very beginning, and other amending powers were later added. ${ }^{15}$ Nevertheless, where no domestic amending formula was available, it was still necessary to go to Westminster to make amendments.

This famous missing provision from the B.N.A. Act provoked a constitutional crisis. Prime Minister Trudeau insisted not only on unilaterally patriating the constitution with alternative amending formulas, but on incorporating in it as well

10. See id. $\S 23(3)$.

11. Parliamentary Debates on Confederation of the British North American ProvINCES, QUEBEC, 1865 at 146, 198, 217, 263, 286, 291, 326, 433, 579, 687, 688, 701, 778, 857, 864, 918, 1010 (1951).

12. R. Dawson, The Government of Canada 26-27 (5th ed. 1970).

13. See, e.g., P. Fox, Politics Canada 15 (4th ed. 1977). The procedure would now seem to be archaic in Britain. See N. Wilding \& P. Laundy, An Encyclopedia Of Parliament 189 (4th rev. ed. 1972): "Addresses to the Queen (in Britain) may be made jointly by both Houses, although this has not been done since 1842 , and they are more often presented by each initial House singly."

14. The British North America Act, 1867, 30 \& 31 Vict., c. 3, reprinted in CAN. REV. STAT. app. II, no. 5 (1970).

15. Id. $\$ 91(1)$ (added by the British North America Act (No. 2), 1949, 13 Geo. VI, c. 81). 
a Canadian Charter of Rights and Freedoms, ${ }^{16}$ extensively derogating from provincial jurisdiction without provincial consent. With a majority (eight out of ten) of the provinces ${ }^{17}$ aligned against him in all regions of the country, including both major party leaders in the important province of Quebec, Trudeau lacked the kind of balanced regional support that was needed to have an amendment passed under either the proposed Victoria or Vancouver ${ }^{18}$ formulas. Six provinces, including Ontario and Quebec and at least two others in each of the Atlantic and Western regions were needed under the Victoria formula, while a minimum of seven provinces were required under the Vancouver formula favored by many of the provinces. Once either of the foregoing amending formulas was in place, the opposition to the constitutional package by Quebec, three out of four Atlantic, and all four Western provinces ensured rejection of the Charter. Prime Minister Trudeau's alternative was to have the Charter enacted by the British Parliament. Accordingly, in the absence of a weighted domestic consensus, Trudeau was obliged to ask a foreign legislative body to enact the "core" of a new Canadian constitution or resign himself to foregoing the Charter entirely. In such circumstances, it is ironic that he charged those who opposed him with "colonialism." Their natural rejoinder would have been that he was asking a non-Canadian legislature to do something which could never be achieved through consensus at home.

The two provinces initially supporting Trudeau were the large central, industrialized province of Ontario, having 36 percent of the country's population (about eight million) ${ }^{19}$ and the Atlantic province of New Brunswick. In each case there were political motivations at work which helped to explain the provinces' position. The federal government, which has exclusive legislative jurisdiction over interprovincial marketing, maintains a domestic price for oil substantially below the international price. Ontario industry has difficulty competing in the world market and benefits greatly from this lower price. The Western energy-producing provinces have been engaged in negotiations with Ottawa on this matter which have not always been amicable. There was, consequently, a widespread perception that the support of Conservative Premier Davis of Ontario for the package involved an understanding, express or implied, that in return for such support Trudeau would maintain acceptably lower domestic prices for energy.

In the case of Premier Hatfield of New Brunswick, approximately one-third of his province's population consists of French-speaking Acadians who would respond warmly to the entrenchment of French-language rights in sections 16 to 23 of the Charter. The Acadians are heavily concentrated in the northern and eastern sections of the province where Hatfield has traditionally been weak and entrench-

16. See the appendix of this issue, p. 265 infra, for the TEXT Of THE RESOLUTION RESPECTING THE Constitution of CANADA ADOPTED By THE HOUSE OF COMMONS ON December 2, 1981 [hereinafter cited as Constitution Act].

17. See The Globe and Mail (Toronto), Mar. 25, 1981, at 1, col. 5.

18. For the original version of the Victoria Amending Procedure see P. Fox, supra note 13, at 28-29; for the version in the Trudeau "package" see Constitution Act $\S 45$ as set out in The Globe and Mail, supra note 8; for the Winnipeg variation of the Vancouver formula, see The Globe and Mail (Toronto), Mar. 26, 1981, at 2, col. 5

19. Premier Davis's Conservatives were reelected convincingly in March 1981, contending that their success at the polls was a reaffirmation by the electorate of the Premier's support for Trudeau's package. 
ment could shore up his party's fortunes, especially with the opposition Liberals having an Acadian leader, Joseph Daigle. In a negative sense, this factor is also at work in Ontario. For political reasons, Premier Davis did not want to accept the institutional bilingualism now mandated for only three provinces by the Charter, since this would antagonize the large provincial English-speaking majority. There is, however, a strong, traditionally liberal, French-speaking minority $(600,000)$ in the province which constitutes a powerful lobby for the extension of French-language rights. The issue has caused Trudeau some embarrassment because of his historical support for bilingualism across Canada. An early measure of his government was the 1969 Official Languages Act. ${ }^{20}$ But he has resisted all efforts to include Ontario among the bilingual provinces to reward the leader of his indispensable Ontario ally.

Virtually all parties and provinces agreed upon patriation with an amending formula. The stumbling block was the sweeping rights Charter. This was hardly an ordinary or minor amendment, and its provisions have met with major opposition in all but two provincial capitals. Prime Minister Trudeau has attempted to deflect some of the opposition (one Gallup poll placed opposition across the country as high as 64 percent) by giving New Democratic Party (N.D.P.) Members of Parliament a sense of coauthorship, enlisting the support of N.D.P. federal parliamentarians who come from the West where his party is very weak. The Liberals have only two M.P.s (from the Winnipeg area) in the four Western provinces. He has also made belated overtures in the Charter to native peoples ${ }^{21}$ and the handicapped, ${ }^{22}$ but these liaisons serve merely to emphasize his lack of provincial support.

Patriation without an amending formula, of course, would be foolhardy. The mere bringing of the constitution to Canada without an amending formula would risk paralysis--there would be no means in the instrument to effect fundamental change.

\section{III}

\section{Prime Minister Trudeau's Constitutional Position}

A persistent goal of Prime Minister Trudeau since long before his entry into politics has been the entrenchment in the constitution of a bill of rights. The son of a self-made millionaire businessman and lawyer, Trudeau received his early training at the elite Jesuit College Jean de Brebeuf, his legal education at the University of Montreal, and his graduate instruction at Harvard University and the London School of Economics. ${ }^{23}$ His education explains in part his cosmopolitan outlook and his rejection of a parochial inward-looking nationalism. A foe of Quebec's durable but authoritarian right-wing Premier Maurice Duplessis (1936$39 ; 1944-59)$, the younger Trudeau was an articulate critic of the Premier's harsh

20. Can. Rev. Stat. c. 0-2 (1970).

21. See Constitution Act, supra note 16, §§ 25, 35.

22. Id. $\S 15($ l).

23. Recent biographies of the Prime Minister are R. Gwyn, The Northern Magus (1980); G. RadWanski, Trudeau (1978). 
repression of the asbestos strike involving 5,000 miners at Asbestos and Thetford Mines, Quebec, in 1949. Duplessis dispatched the Quebec provincial police to intimidate and harass the strikers. The next year Trudeau was a principal founder of the intellectual journal Cite Libre which vowed implacable opposition to the Duplessis regime.

The young Trudeau had no declared formal ties to the Liberal Party, possibly having a stronger affinity for democratic socialism than for liberal democracy. ${ }^{24}$ He realized that the socialist-oriented N.D.P., which was virtually nonexistent east of the Ottawa River (the Quebec-Ontario boundary) had no prospect of forming a federal administration. He was attracted to the idea of moving the Liberal Party more to the left in 1962, but derisively rejected Liberal opposition leader Lester B. Pearson's reversal of party policy at Scarborough, Ontario, on January 12, 1963, when the latter agreed to accept nuclear warheads in furtherance of Canada's controversial NATO and NORAD commitments. ${ }^{25}$ His opposition, however, was short-lived. Only two years later, he joined Quebec labor leader Jean Marchand and journalist Gerald Pelletier as Quebec Liberal candidates in the 1965 general election hoping to give the patronage-slanted Quebec Party a more progressive image. In doing this, Trudeau was obliged to accept the same policy he had criticized so sharply just two years before.

Appointed Minister of Justice in the Pearson cabinet in 1967, he ran successfully for the party leadership in $1968,{ }^{26}$ when his harsh criticism of Pearson's reversal of nuclear policy was circulated by his opponents in the hope of stemming a strong tide in his favor. He was chosen leader by the delegates and won a majority mandate in Parliament soon after in the 1968 general election.

In the October crisis of 1970 , involving the kidnapping by the terrorist Front de Liberation de Quebec (F.L.Q.) of British Consul-General James R. Cross and the murder of Quebec provincial Labor Minister Pierre Laporte, Trudeau invoked for the first time in peacetime the War Measures Act on grounds of apprehended insurrection. ${ }^{27}$ More than three hundred Québecois were placed under preventive detention pursuant to this statute, of whom virtually none were ultimately found guilty of any offense. He also invoked peacetime emergency powers to impose sweeping wage and price controls in $1975 .{ }^{28}$

The "independantiste" option of former provincial Liberal cabinet minister Réne Lévesque, who founded the separatist Parti Québecois in the late sixties, was anathema to Trudeau. Lévesque was elected Quebec Premier in November 1976. ${ }^{29}$ Trudeau regarded the federal consensus in a territorial nation-state as an act of

24. See, e.g., TRudeau, The Practice and Theory of Federalism, in Federalism And THE FRENCH CANADIANS 127 (1968) [hereinafter cited as Trudeau]: "[D]ifferent regions or ethnic groups in Canada are at vastly different stages of their political development . . . . [I]t is folly to endorse strategies that are devised to swing the whole country at the same time and in the same way into the path of socialism." This essay was originally written in 1961, before Trudeau entered politics.

25. P. Stursberg, Lester Pearson and the Dream of Unity 80 (1978).

26. Id. at ch. 14, for an account of the leadership race at the 1968 Liberal Convention.

27. See RADWANSKI, supra note 23 , at 295-304.

28. The constitutional validity of wage and price controls was upheld by the Supreme Court of Canada in Reference re Anti-Inflation Act, 68 D.L.R.3d 452 (1967).

29. P. Desbarats, RENE 251 (1977). 
political will transcending parochial ethnically based nationalisms: "[I]t becomes apparent that more than language and culture, more than history and geography, even more than force and power, the foundation of the nation is will. For there is no power without will. The Rocky Mountains are higher than the Pyrenees but they are not the watershed between countries."30

Lévesque set the first of two proposed referenda on "sovereignty-association" (independence for Quebec with an economic association along common market lines, regulated by an international treaty with a politically reconstituted English Canada) for May 20, 1980. If the Quebec electorate voted "yes" to his request for a mandate to negotiate, a second referendum would be held later to confirm the negotiated terms of separation. Trudeau energetically entered the campaign, refusing even to envisage negotiation in the event of an affirmative vote. He promised in the event of a "no" vote to forge a new constitution more acceptable, among other things, to French Canada. His continuing position was that French Canada was more extensive than the Francophone community in Quebec, having large elements in Eastern Ontario and Northern New Brunswick, and that as prime minister of the whole of Canada he could speak for French Canada as authoritatively as Premier Lévesque. (As mentioned above, his reluctance for tactical reasons to extend institutional bilingualism to Ontario in a new constitution is an achilles heel in this policy.) The May referendum resulted in a 60 percent vote against separation. Visibly shaken by the result, and having experienced a whole series of electoral setbacks to Claude Ryan's Liberals, Lévesque shelved at least temporarily his independence proposal. Campaigning on a social democratic platform, his Parti Québecois swept into power again on April 13, 1981, winning exactly two-thirds of the seats in the one-chamber Quebec National Assembly. Despite the Quebec Premier's separatist rhetoric, which they tended to discount, the seven other premiers opposing Ottawa's constitutional plans were heartened by his reelection.

Like Conservative Prime Minister John Diefenbaker, Trudeau has traditionally been a believer in "one Canada," without constitutional special status for any province. His aim has been to establish a political community in which Frenchand English-speaking Canadians would have general access, anywhere they reside in sufficient numbers, to federal government services in either official language. Accordingly, he wished to extend elementary and secondary school rights for citizens of either language "where numbers warrant"31 (the limitation of the rights to citizens could exclude some immigrants not yet naturalized, whom Quebec wished to send to the French-speaking schools), and to make French- and Englishspeaking radio and television available almost everywhere in the country for members of the two "founding cultures." 32 He also thought that use of French in courts

30. See Federalism, Nationalism and Reason, in Trudeau, supra note 24, at 187.

31. See Constitution Act, supra note 16, $\$ 23$.

32. The original formal commitment to this concept was made by Prime Minister Lester B. Pearson when he established the Royal Commission on Bilingualism and Biculturalism in 1963. See Stursberg, supra note 25 , at 309 . 
and legislatures should be promoted in as many provinces as possible outside Quebec.

Bilingualism and biculturalism were promoted as a "national myth" in 1963 when Prime Minister Pearson instructed the Dunton-Laurendeau Royal Commission to conduct their inquiries on the basis of two founding cultures. Among other things, the Commission recommended that the federal public service become throughly bilingual. Canadians of German, Ukrainian and other origins, especially in the West, have at times been sensitive to allusions to biculturalism, since they conceive that their cultures are also important elements of the Canadian mosaic. Former Prime Minister Diefenbaker condemned the whole enterprise as divisive and productive of separatist tendencies in the West. The implementation of official bilingual policies led (i) to the enactment of the Official Languages Act, ${ }^{33}$ (ii) to accelerated promotion and pay increases for bilingual federal public servants and members of the armed forces, and (iii) to one year study leaves for federal employees to obtain proficiency in either language, especially in Quebec City and Toronto where students studied the culture as well as the language of the other group. After the expenditure of many millions of dollars, the program was found to be inefficient and was greatly reduced in scope in the late 1970s.

Along with his commitment to bilingualism and biculturalism, Trudeau has long been a proponent of the entrenchment of fundamental rights. As early as 1955 in his submission to the Quebec Tremblay Commission he proposed "the incorporation of a declaration of human rights in the constitution on the condition that the rights of disallowance and reservation be done away with."34 Several years later, while refusing to accord "an absolute and eternal value" to any political structure, he urged the safeguarding in fundamental law of the basic principles of liberty and democracy. As Justice Minister in 1967, he referred approvingly to Prime Minister Pearson's suggestion that a federal-provincial conference be called "to discuss the possibility of adopting a constitutional Bill of Rights binding on both the federal and the provincial governments."35 Perhaps his education in the United States and his dislike of the authoritarian Duplessis regime were among the factors leading him to espouse a charter of rights. He is also a rationalist, a Cartesian, fond of quoting Plato and Aquinas, and having strong ties to the natural law and natural rights traditions. As a political thinker Trudeau is eclectic and difficult to characterize. In Bill C-60, an abortive constitution he ordered drafted in 1978 , there were provisions reflecting both popular sovereignty ${ }^{36}$ and the sovereignty of the Crown. ${ }^{37} \mathrm{He}$ is accused by some of his adversaries, such as Manitoba's Premier Lyon, of being a covert republican. He has referred approvingly to Montesquieu's doctrine of checks and balances, typical of the presidential system, as a device for preventing abuses, while establishing a strong federal system in which the provinces and the center function as counterweights in a dynamic

\footnotetext{
33. Can. Rev. Stat. c. 0-2 (1970).

34. A Constitutional Declaration of Rights in Trudeau, supra note 24, at 53.

35. Id. at 55 .

36. Government of Canada, The Constitutional Amendment Bill 1978, $\S 4$.

37. Id. at 30 .
} 
equilibrium producing both tension and harmony. ${ }^{38}$ His proposals to entrench the present statutory Canadian Supreme Court and to adopt a rights charter would surely affect the principle of parliamentary supremacy, and thus have republican overtones.

The Prime Minister's actions defy easy categorization. On one hand, Trudeau the authoritarian imposed the War Measures Act ${ }^{39}$ in peacetime in 1970 and assumed the powers of an economic czar by his 1975 wage and price controls. On the other hand, he changed the criminal law to make homosexuality between consenting adults lawful on a nationwide basis ${ }^{40}$ and to make abortion more accessible. ${ }^{41}$ In 1976, his government abolished capital punishment. ${ }^{42}$ The foregoing measures were not widely supported in the country. In advocating these changes both his leadership and his elitism were in evidence. Perhaps the same elements are present in his advocacy of an entrenched charter of rights.

\section{IV}

\section{The Amending Power Controversy}

The debate concerning the true nature of the United States Constitution, in which Senator John C. Calhoun was the protagonist of states' rights and Senator Daniel Webster the champion of centralized power, had reverberations in Canada, where adherents of the so-called "compact theory" later developed an argument similar to Calhoun's. Calhoun likened the Constitution to a compact or treaty between sovereign states, each of which had the power to determine whether the government in Washington, which was essentially their agent, had usurped powers never properly entrusted to it. As a corollary, in a case of usurpation, aggrieved state legislatures by resolution could nullify such laws. ${ }^{43}$ Webster held that the Constitution established a government, not a compact, but agreed with Calhoun that the states could secede if the latter were the case. ${ }^{44}$

The Canadian version of the compact theory focused not on nullification but on the amending power. ${ }^{45}$ Its proponents asserted that the B.N.A. Act was a pact between the provinces, and, in the absence of an explicit amending formula, no amendments could be made without the consent of all the original parties, or the parties (provinces) later adhering to the compact. Judge T. J. J. Loranger of Quebec, an early articulator of the theory, did not go as far as Calhoun. He attributed not superiority but absolute equality to the regions in relation to the central government. ${ }^{46}$

38. Trudeau, supra note 24 , at xxiii. See RADWANSKI, supra note 23 , at 136-37.

39. Can. Rev. Stat. 1970 c. W-2 (1970).

40. W. McConnell, Commentary on the British North America Act 239 (1977).

41. Can. Stat. $1968-69$, c. $38, \S 18$ (1969).

42. MCCONNELL, supra note 40 , at 239 .

43. See C. Boucher, Nullification Controversy in South Carolina (1916). In Canada it is

Parliament which can "nullify" provincial laws by the veto power in section 90 of the B.N.A. Act.

44. Id. at 121-23.

45. See, e.g., J. Beck, The Shaping of Canadian Federalism: Central Authortty or ProvinCIAL RIGHTS? 32-55 (1971)

46. Loranger, LetTres sur L'interpretation de la CONSTITUtion Federale 45-61 (1883). 
In the wake of Prime Minister Macdonald's centralization of nineteenth-century Canada, the first interprovincial conference convened at Quebec City in 1887. While apprehensive of growing central power, the compact theory did not figure much in their deliberation, although it was inherent in their policy views. A prominent liberal newspaper, widely regarded as a voice of provincial interests, expressed the most far-reaching version of the theory in the following year: "The Dominion was the creation of these Provinces. . . . The Dominion being nonexistent at the time the bargain was made, was plainly not a party to the bargain."47 The implication of this variant of the theory would be exactly the opposite of what Trudeau proposed in that it would be provinces, and not the federal government, who would be in position to secure amendments to the B.N.A. Act unilaterally. Current supporters of the compact theory would not take such an extreme position.

The Canadian compact theory has had many influential disciples in the twentieth century. Especially popular in Quebec, French-Canadian politicians such as Henri Bourassa and Premiers L. A. Taschereau and Maurice Duplessis have adopted it. (Separatist Quebec Premier Rene Lévesque contends that the contemporary Canadian nation-state is highly centralized, and advocates a return to the compact theory or a true confederation in the form of a sovereignty association between Quebec and English Canada. ${ }^{48}$ ) In the present constitutional controversy Premier Sterling Lyon of Manitoba stoutly maintains that no constitutional amendment affecting the whole federation is possible without the concurrence of all of the provinces. Seven other provinces have adopted that extreme position before the courts. Saskatchewan's Premier Blakeney considers that this position is possibly too rigid, and would accept amendments proposed by Parliament and a weighted majority of the provinces regionally distributed. It was an Englishspeaking advocate of the compact theory, Ontario Premier G. Howard Ferguson, who was instrumental in having section 7 inserted in the Statute of Westminster, 1931.49 The effect of that section was to negate the possible inference that Parliament's legislative powers, arising from the newly proclaimed sovereign and coordinate status of the Dominion, would enable it to alter unilaterally the B.N.A. Act or its amendments up to $1930 .{ }^{50}$ In a memorandum addressed to Conservative Prime Minister R. B. Bennett, Ferguson referred to the fact that although each province had its own amending power, no similar power had been conferred on Ottawa:

If the power to amend the Constitution had been vested in the Dominion, it is probable that the long and hitherto successful controversy as to the constitutional rights of the provinces would have had a different outcome, because at any stage of the struggle the Dominion Parliament would have had power to enact legislation setting aside the rights of the provinces. ${ }^{51}$

47. The Toronto Globe, Mar. 9, 1888. See R. Brown \& M. Prang, Confederation to 1949 (1966).

48. The Globe and Mail (Toronto), Mar. 30, 1978, at 7, col. 2.

49. 22 Geo. V, c. 4 (U.K.)

50. Letter and Memorandum of Hon. Howard Ferguson, The Toronto Globe, Sept. 20, 1930 in R. DAWSON, CONSTITUTIONAL IsSues IN CANADA, 1900-1931, at 28-34 (1933) [hereinafter cited as DAWSON]. See K. Wheare, The Statute or Westminster and Dominion Status (1953).

51. DAWSON, supra note 50 , at 31 . 
Section 7 of the Statute of Westminster has given rise to a concept sometimes called residual trusteeship. According to this concept, if it is manifest, as it is in the present case, that the amendment sought by a Joint Address was opposed by one or more provinces, it might be necessary for the government of the United Kingdom or Parliament to go behind the request in order to determine if provincial powers were unconstitutionally being diminished without provincial consent. In the words of the Kershaw Report:

\begin{abstract}
[A]t the invitation of Canada, the U.K. Parliament assumed the continuing role of enacting amendments to the Canadian constitutional system. The explicit purpose of the Canadian invitation was that the pre-1931 status quo, in relation to constitutional amendments, be retained until such time as agreement could be reached by the appropriate Canadian authorities on methods of constitutional amendment within Canada itself. The U.K. authorities accepted their constitutional role, conscious of the risk that at some future time it might involve them in friction and political embarrassment. ${ }^{52}$
\end{abstract}

An outstanding British constitutional authority, Professor H.W.R. Wade, Master of Gonville and Caius College, Cambridge, and an advisor to the Government of Quebec in the present controversy, but a publicist whose views were formed before he was retained in that capacity, has said of section 7:

The inescapable conclusion is that [section] 7 of the Statute of Westminster 1931 has left the U.K. Parliament with not only legal but also political responsibility for upholding the federal constitution of Canada and acting as guardian of the rights of the provinces. Anachronistic and unwelcome as this responsibility may be, it was deliberately preserved in 1931 and nothing has since happened to alter it. The U.K. Parliament therefore has the duty, when requested to amend the British North America Acts, to ask itself two questions: first, does the amendment adversely affect Provincial legislative powers; and secondly, if so have the Provinces affected signified and their consent ${ }^{53}$ ?

In the present context, Wade would answer the first question yes and the second no. His advice to the British authorities is straightforward: "The simplest course would be for it (the U.K. Parliament) to enact a short statute empowering the Government of Canada to amend the British North America Acts in any manner, provided that the consent of all the provinces was obtained."54 (Kershaw, conversely, suggests taking notice of Canada's federal structure and doing nothing until provincial concurrence is obtained. ${ }^{55}$ ) A difficulty with Wade's proposed procedure is that section 4 of the Statute of Westminster forbids the U.K. Parliament from legislating for a Dominion after 1931 without the express request and consent of that Dominion. A positivistic view would therefore suggest that Wade's recommendation was unconstitutional. He might retort, however, that the federal government's action also was unconstitutional, that the residual trusteeship arising from section 7 was a higher norm, since it was the very sine qua non of continued federalism, and that it was necessary to give paramountcy to section 7 in these circumstances. This procedure would reflect, of course, the principle of the supremacy of the British Parliament, not in the old colonial sense but in further-

52. Great Britain, House of Commons, first Report from the foreign Afyairs ComMITTEE, 1980-81, (KERSHAW REPORT) $l x i$ [hereinafter cited as Kershaw Report].

53. H. Wade, Amendment of the Constitution of Canada: The Role of the United Kingdom Parliament, 8-9 (Nov. 24, 1980) (unpublished memorandum).

54. Id. at 9 .

55. Kershaw Report, supra note 52, at $\mathbf{l x i}$. 
ance of the British obligation to Canada as a structured federal whole to preserve the very conditions of that federalism.

In view of section 7, one might ask the question, if the Dominion cannot directly amend the various B.N.A. Acts effectuated between 1867 and 1930, could it do essentially the same thing against provinicial wishes by unilaterally sending a Joint Resolution to London to have the British perform that task? The answer must certainly be no. Was there not an understanding underlying section 7 that entrenched provisions relating to provincial powers would be amended only with provincial consent? The courts could take judicial notice of the documents reflecting such an understanding. If this were not the understanding, section 7 would appear to be redundant.

At the center of the constitutional debate in Canada has been the question of whether or not a constitutional convention exists requiring federal-provincial agreement prior to securing a constitutional amendment derogating from provincial powers. On February 3, 1981, the Manitoba Court of Appeal ruled in a 3-2 reference decision that provincial agreement was not essential for constitutional change, even if such change resulted in a reduction of provincial powers. ${ }^{56}$ In a 4-1 decision, the Quebec Court of Appeal came to essentially the same result, but the Newfoundland tribunal decided unanimously against the federal government. ${ }^{57}$ The Province of Manitoba announced its intention immediately to appeal the decision to the Supreme Court of Canada. Pursuant to a meeting of provincial premiers in the fall of 1980, six provinces had decided to initiate or support references to provincial supreme courts in Manitoba, Quebec and Newfoundland. Only the federal government had legislative authority to ask the Supreme Court of Canada for a reference opinion on the constitutionality of its package, ${ }^{58}$ and it was resolved not to do so. Accordingly, the only way in which the aggrieved provinces could get before the federation's ultimate tribunal was to initiate references in provincial courts which could then be appealed in the event of an unfavorable decision, or which the federal government, because of the force of public opinion, would be likely to appeal in case of a provincial victory. In light of the uncertain precedents, the provinces were assuming a risk by taking court action, but in view of the boldness and the unilateral character of the federal initiative they did not have many options, and they probably considered that a favorable decision would strongly reinforce their claim that the federal action was unconstitutional; an adverse ruling, of course, would substantially weaken their claim. The ultimate ruling on the convention powerfully reinforced their position, enabling them to make a much stronger compromise.

In the modern period the amendments bearing most closely on the present

56. Reference $r e$ Amendment of the Constitution of Canada, 117 D.L.R.3d 1, 2 (1981).

57. For the Quebec and Newfoundland reference opinions, see, respectively, Reference $r$ Amendment of the Constitution of Canada (No. 3), 120 D.L.R.3d 385 (Que. 1981) and Reference re Amendment of The Constitution of Canada (No. 2), 118 D.L.R.3d 1 (Nfd. 1981).

58. See The Supreme Court Act, Can. Rev. Stat, c. S-19, $\$ \$ 55(1)$ (b), (d) (1970). 
controversy are those enacted in $1930,{ }^{59} 1940,{ }^{60} 1949,{ }^{61} 1951,{ }^{62} 1960,{ }^{63}$ and 1964.64 The amendments secured in 1930 and 1949 are somewhat peripheral since they do not affect the legislative powers of the provinces. The amendment of 1930 transferred to the prairie provinces ownership of the public domain (lands and minerals) within their boundaries which had been retained by Ottawa for railroad building and settlement when those provinces joined the Confederation. There were protracted negotiations before the amendment was obtained, and the consent of each of the provinces concerned was secured. The first amendment of 1949 added the Province of Newfoundland to the federation. The second incorporated what the federal parliament, but not the provinces, had lacked since 1867: a circumscribed federal amending power enabling Parliament to amend matters (e.g. , the number of seats in the House of Commons) falling exclusively within federal jurisdiction. ${ }^{65}$ The express saving clause safeguarding provincial jurisdiction makes this clear, as it excludes from Ottawa's reach changes

as regards matters coming within the classes of subjects by this Act assigned exclusively to the Legislatures of the provinces, or as regards rights or privileges by this or any other Constitutional Act granted or secured to the Legislature or the Government of a province. ${ }^{66}$

A letter from Prime Minister L.S. St. Laurent to Premier T. C. Douglas of Saskatchewan just before the above amendment was obtained conveys the message of courteous reassurance that the desired amendment will not encroach on provincial powers:

Such an amendment would give the Canadian Parliament the same jurisdiction over the purely federal aspects of our constitution that the provincial Legislatures already possess over the provincial constitutions, while giving both to provincial rights and jurisdiction and to the historic right of minorities an express assurance of legal protection which we feel they should have. ${ }^{67}$

The same letter looks to a meeting with all the provinces soon to devise a generally satisfactory method for making amendments affecting the whole constitution.

The amendments of 1940 (centralization of unemployment insurance), 1951 (jurisdiction to make laws in relation to old age pensions), 1960 (tenure of office of provincial superior court judges), and 1964 (supplementary benefits to old age pensions) affected provincial legislative powers and in each instance the consent of all of the provinces was obtained. In the case of the 1940 unemployment insurance amendment, Quebec's reluctance to agree delayed the amendment for several years. In commenting on this delay, Prime Minister King said in Parliament that the eventual securing of unanimous consent had forestalled the need to answer the

59. British North America Act, 1930, 20 \& 21 Geo. V., c. 26.

60. British North America Act, 1940, 3 \& 4 Geo. VI, c. 36.

61. British North America Act, 1949, 12 \& 13 Geo. VI, c. 22 [hereinafter cited as B.N.A. (No. 1) Act, 1949] and British North America (No. 2) Act, 1949, 13 Geo. VI, c. 81 [hereinafter cited as B.N.A. (No. 2) Act, 1949].

62. British North America Act, 1951, 14 \& 15 Geo. VI, c. 32.

63. British North America Act, 1960, 9 Eliz. II, c. 2.

64. British North America Act, 1964, 12 \& 13 Eliz. II, c. 73.

65. B.N.A. (No. 2) Act, 1949, supra note 61.

66. Id.

67. Letter from L. St. Laurent to T. Douglas, Sept. 14, 1949. 
question whether "it is absolutely necessary to secure the consent of all provinces."68 He thus implied, as Wade contends, that convention made it at least "absolutely necessary" to obtain the consent of some of the provinces. The practice on this occasion would indicate, indeed, that the consent of at least a clear majority was necessary.

At the turn of the century (1896-1911), Prime Minister Sir Wilfrid Laurier referred to the Confederation as a compact of nine provinces, and added that the federal constitution "should be altered only for adequate cause, and after the provinces themselves have had an opportunity to pass judgment on the same. . . $[T]$ his House ought to hesitate in passing judgment until it has before it the views of all the provinces affected."69 The impossibility of obtaining the consent of the provinces to entrenchment prompted Prime Minister John Diefenbaker, the sponsor of the statutory (i.e., unentrenched) Canadian Bill of Rights, to have his primordial charter extend to federal laws alone, since he conceived that unanimous consent would be needed to have it entrenched: "My experience with the provincial governments indicated that they were too jealous of their jurisdiction over property and civil rights to support any amendment applicable to themselves."70 Diefenbaker's successor, Lester B. Pearson, unsuccessfully attempted to obtain provincial consent to an earlier amending proposal known alliteratively as the Fulton-Favreau formula (after the two federal Ministers of Justice who developed it). In writing to each of the premiers in 1964, Pearson said: "We will proceed with the preparation of a Resolution ... as soon as we have received confirmation from all provinces regarding the accuracy of the test, and their concurrence (by their Legislatures) in the substance of the proposed Act."71 On February 6, 1979, only eighteen months before the present controversy erupted, Prime Minister Trudeau addressed the Federal-Provincial Conference of First Ministers on the Constitution. In response to questions from the premiers on the ground rules of constitution-building, Trudeau said:

We will adopt a Charter of Human Rights, we will constitutionalize it. We cannot force
the provinces to do it. We are trying to convince them to do it . . . I can answer unequiv-
ocally that the federal government intends to entrench a charter of basic human rights and
of linguistic rights. Now this will bind the federal government; it won't bind the provinces
unless they want to bind themselves . . . The final question was one of unanimity. We
had the rule of unanimity, says Premier Bennett in $1971 . .$. I think it is clear from what
we said ourselves Sunday night that this conference has also accepted the rule of unanimity
$\ldots$. . La, on ne peut pas sortir du statu quo sans le consentement de toutes les provinces.

These statements evince a conviction that there is a certain symmetry in the Canadian federal constitution. Since 1949 both the federal and provincial governments have had legislative jurisdiction, without the need for a Joint Address, to amend those parts of the constitution falling exclusively under their respective

68. Wade, supra note 53 , at 5 .

69. Province of British Columbia, Submission of the Government of British Columbia to the Foreign Affairs Committee, House of Commons, London, England, at 39 (Victoria, B.C., 1981) [hereinafter cited as Submission to Foreign Affairs].

70. $2 \mathrm{~J}$. Diefenbaker, ONe Canada 212 (1976).

71. Submission to Foreign Affairs, supra note 69 , at 42

72. Id. at 43 . 
powers. ${ }^{73}$ For other matters, such as the reconstitution of the federal upper house $^{74}$ or the alteration of the federal-provincial division of powers, a Joint Address supported by a federal-provincial consensus is still needed since such matters reciprocally affect both the central and the regional units. The transfer of powers adds to one unit's jurisdiction while subtracting from another's (e.g., centralization of unemployment insurance) so that it would be impermissible under a domestic legislative provision for either federal component to achieve such a modification unilaterally. Diminution of a party's powers via a charter should also have that party's consent. Such a fundamental change must pertain to a larger "Constitution of Canada" beyond the reach of either unit, and must be subject to amendment only by a rigid amending formula. If this were not so the final result would either be balkanization or a unitary state. In such a case, the federal principle itself is at stake.

Central to the concept of Canadian federalism is the notion that Parliament and the provincial legislatures each exercise exclusive legislative powers in those areas in which they are respectively supreme. As one of the leading Canadian authorities on constitutional amendment, Paul Gerin-Lajoie, has argued, constitutional enactments and judicial interpretation have established that within its appropriate sphere each province is free from legislative interference by Parliament. Neither is a province subordinate to the United Kingdom nor its Parliament. Should the Canadian Parliament by Joint Address seek an amendment affecting provincial powers without provincial consent it would violate both law and convention. ${ }^{75}$ From this it is clear that an attempt to totally revise the Constitution, or to adopt a new amending process, without provincial consent, would "constitute the most sweeping infringement of provincial sovereignty."76

In 1965, Liberal Justice Minister Guy Favreau issued a white paper surveying the amending process in a historical framework and drawing therefrom certain general propositions. While Favreau emphasized throughout the paper that the United Kingdom Parliament would not act on a specific request transmitted by the Parliament of Canada alone, and that the provinces lacked standing to initiate such a request, his fourth general principle affirmed that "the Canadian Parliament will not request an amendment directly affecting federal-provincial relationships without prior consultation and agreement with the provinces."77 The white paper later added: "In fact in the [ninety-seven] years that have elapsed since Confederation, no amendment has altered the powers of provincial legislatures under section 92 of the British North America Act without the consent of all the provinces."78

73. The provincial power is contained in $\S 92(1)$ of the B.N.A. Act, and the federal equivalent was enacted in 1949 by B.N.A. (No. 2) Act, 1949.

74. Reference re Legislative Authority of Parliament to Alter or Replace the Senate, 1 S.C.R. 54 (1981), 102 D.L.R.3d 1 (1979).

75. P. Gerin-Lajoie, Constitutional. Amendment in Canada 167-68 (1950). After the above work was written the Supreme Court of Canada in Attorney General of Man. v. Attorney General of Can., [1981] 6 W.W.R.13 (1981), found that there would be a violation of convention but not of law.

76. Gerin-Lajoie, supra note 75 , at 163.

77. G. Favreau, The amendment of The Constitution of Canada 15 (1965).

78. Id. at 47. 
Quite apart from the question of whether the provisions proposed in the current constitution have merit or not, it is obvious that many of them will diminish local powers. For example, the freedom of expression provision in section 2 could interfere with provincial movie censorship or defamation laws, and the freedom of peaceful assembly ${ }^{79}$ could impose a new legislative standard which provinces and municipalities would have to meet in regulating the use of public thoroughfares. Section 4(l) explicitly prescribes a five-year maximum duration for provincial legislatures, thus preventing the substitution of a shorter term if, as in Australia and New Zealand, that policy were regarded as more democratic. Section 6 defining mobility rights could affect the validity of provincially established professional qualifications which might be interpreted as discriminating against residents of other provinces. The prohibition in section 8 against unreasonable search and seizure could have diverse provincial ramifications, such as making local fire, liquor, sanitary, or building $\operatorname{code}^{80}$ inspections legally impermissible without a search warrant, or making it more onerous for provincial social workers to inspect premises where children were in the legal custody of others. ${ }^{81}$ The right of equality granted by section 15 , of course, could have potentially vast provincial significance relating to employment practices, public facilities and general legislative standards, especially the novel prohibitions against discrimination based on age or mental or physical disability. The rights of citizens of Canada to be educated in either English or French at public expense where numbers warrant, as set out in section 23, could impose burdensome new responsibilities on provincial departments of education, education being an exclusively provincial matter. Finally, the method of amending the constitution or arriving at a new amending formula, a provision vitally affecting the durability of local powers, has been prescribed by the central government, with a preferred place being given to the Victoria formula and an unheralded referendum process.

In assesing the impact of these proposals, it is just as important to look to their laxity and imprecision as it is to determine the extent to which they derogate from provincial jurisdiction. The vagueness and generality of some of the provisions could present the courts with a formidable interpretative task. When approaching this issue, it must be remembered that in a parliamentary system where courts play a more subordinate role, the kind of creative judicial activism often found on the United States Supreme Court is rare. What are the chances that the libertarian provisons in the Charter will be instilled with real life? Surveying the judicial disposition of Diefenbaker's statutory Canadian Bill of Rights, ${ }^{82}$ one of the most liberal of recent Canadian Supreme Court judges said: "In the space of three years from Drybones to Lavell the bill of rights went from a high point of great expectancy to near oblivion."83 The 1970 Drybones ${ }^{84}$ decision affirming racial equality, the soli-

79. Constitution Act, supra note $16, \S 2$.

80. For a U.S, analogy relating to building codes, see Camara v. Municipal Court, 387 U.S. 523

(1967).

81. See Wyman v. James, 400 U.S. 309 (1971).

82. Can. ReV. Stat. app. III (1970).

83. Hall, The Supreme Court in the New Canada, in Cronkrte Memorial Lectures 16 (1978).

84. Regina v. Drybones, 9 D.L.R.3d 473 (1970). 
tary landmark case on the Bill, was succeeded in three short years by Lavell ${ }^{85}$ in which the same court denied equality on the basis of sex in circumstances which the dissenting Chief Justice found indistinguishable from Drybones ${ }^{86}$ The conservative direction of many of the court's civil liberties decisions is attributable to its tendency to set the principle of the supremacy of Parliament beside provisions in the Bill of Rights and to theorize that even in the case of a clear collision, if Parliament unequivocally meant what it said, the clearly contrary provisions in the Bill of Rights could not stand against it: ${ }^{87}$ Parliament, rather than a statutory bill of rights, is supreme and parliamentary intention must prevail. Whether the proposed new Charter will receive a more effective interpretation is questionable.

What does a guarantee to "life, liberty and security of the person" that cannot be taken away "except in accordance with the principle of fundamental justice" in section 7 mean? And what does the sinister-looking provision in the very first section signify? That the enumerated guarantees of rights and freedoms are subject only "to such reasonable limits prescribed by law as can be demonstrably justified in a free and democratic society?" It leaves a loophole as big as a small ocean for equivocating lawyers and judges, facilitating the undermining of every substantive rights provision in the Charter. Is there any provision similar to this in the United States Constitution? Implications for priority based on the placement of this section are also very disquieting. A first amendment absolutist like Mr. Justice Black would shudder with disbelief.

The Victoria amending formula was always Prime Minister Trudeau's preference. A modified version of the 1971 formula was included in his unilateral package until the November Fifth Accord was struck with the premiers, at which time their alternative formula was substituted for it. ${ }^{88}$ The modified Victoria amending formula would have required the approval of the Senate and the House of Commons and of every provincial legislature in a province which has, or has had, 25 percent of the population (at present, Ontario and Quebec), along with any two Western and any two Atlantic provinces. ${ }^{89}$ Under that formula, even if the relative populations of Quebec or Ontario had declined to less than 25 percent in relation to the whole, their concurrence on future amendments would still be required since the applicable provision reads population "at any time."

The Victoria amending formula was not liked by some because it gave a permanent veto over future amendments to each of the two provinces in the central region of the country whose economic interests (e.g., freight rates, tariff policy or

85. Attorney General of Can. v. Lavell, 38 D.L.R.3d 481 (1974).

86. Id. at 501 .

87. See, e.g., the dissenting opinion of Justice Abbott, in Dybones which represents the more typical approach of the Court: "The interpretation of the Canadian Bill of Rights, 1960 (Can.), c. 44, adopted by the courts below, necessarily implies a wide delegation of the legislative authority of Parliament to the courts. . . . In my view, it would require the plainest words to impute to the Parliament an intention to extend to the Courts, such intention to engage in judicial legislation." 9 D.L.R.3d at 477 (1970). See also the dissenting opinions of Justice Pigeon, 9 D.L.R.3d at 491, and Chief Justice Cartwright, 9 D.L.R.3d at 47677.

88. The Globe and Mail (Toronto), Nov. 6, 1981, at 13, col. 1 .

89. See the original version of the Constitution Act, supra note 8 , now superseded by the November Accord, reprinted in The Globe and Mail (Toronto), supra note 88. 
energy prices) were often in conflict with those of the coastal provinces. In neither the United States ${ }^{90}$ nor Austrialia ${ }^{91}$ do the amending procedures give a veto power to specified individual units.

One of the most controversial features of the whole proposed amending scheme was the now-deleted popular referendum procedure envisaged in section 46 . What Premier Blakeney and some of the other premiers found especially obnoxious about this provision was that the amending procedure could be activated only by the federal government. There was no mutuality. They stressed that the federal government would have the initiative in financing, timing, advertising and the wording of the referendum question. While the provinces would have had one appointee on a three-member Referendum Rules Commission, ${ }^{92}$ the federal government would have had a majority with the federally appointed Chief Electoral Officer acting as chairman and one other federally appointed member.

The original proposal was to make the referendum procedure a full-blown alternative to the Victoria formula, or its substitute. However, strong provincial protests that such a device could be fixed by the federal government caused the proposal to be shelved. According to the final text, a referendum would be employed only where a proposal had been advanced under the Victoria or a similar formula and failed to gain provincial concurrence within twelve months; ${ }^{93}$ a referendum would then be held within an ensuing two-year period. ${ }^{94}$

The position of the Senate in the amending process became a deeply contentious issue between the federal and provincial branches of the New Democratic Party. The N.D.P., variously described as democratic-socialist or social-democratic in tendency, is perhaps more populist than socialist in character, similar to the midwestern Farmer-Labor Party in Minnesota. It has long advocated the abolition of Canada's appointed 102-member Senate which is widely regarded as the elitist preserve of corporate directors, party bagmen and tired politicians.

The Trudeau government had in 1979 proposed the replacement of the Senate with a "house of the Federation" by means of ordinary statute. Following a constitutional reference, the Supreme Court of Canada found that proposal unconstitutional. ${ }^{95}$ Under section 44 of the unamended proposals put forward in the fall of 1980,96 the Senate was to possess only a ninety-day delaying power over constitutional amendments. Faced with a serious incipient revolt by senators, however, the federal government deleted the section. The government apparently feared that the Joint Resolution, which was without provincial consent, would not obtain the necessary approval of the upper house required to dispatch it to London.

90. U.S. Const. art. V.

91. The principal amending part of the Australian Constitution (art. 128) provides for amendment by a majority of all the electors voting in a majority (at present four out of six) of the states. See K. WHEARE, FEDERAL GOVERNMENT 56 (4th ed. 1963).

92. Constitution Act, supra note 16, § 44(2).

93. Id. $\S 46(2)(\mathrm{b})$.

94. Id. $\S 46(3)$.

95. See Reference re Legislative Authority of Parliament to Alter or Replace the Senate, 1 S.C.R. 54 (1981), 102 D.L.R.3d 1 (1979).

96. Government of Canada, The Canadian Constitution, 1980 (1980). 
Some Canadians ask why an unelected and elitist group like the Senate, often held to be a sanctuary of special interests and responsive to nobody, should possess a permanent veto, equal to that of the elected House of Commons or the provinces, over constitutional amendments. It would certainly be in a position to forestall any amendment threatening its own abolition or reconstitution. This was particularly pertinent in that deliberations on the composition and character of a new upper house would be the next order of business in constitutional renewal after the disposition of the present Joint Resolution. The Senate might have been able to block a unilateral resolution, since it could have appealed to eight supportive provincial premiers. Unlike the United States Senate, it lacks a popular constituency of its own; but opinion in the country was deeply divided, and it would have found many allies before November 5, 1981. When the Accord was made, however, the possibility of obstruction dissipated and the Senate's absolute veto was converted into a mere 180-day delaying power. ${ }^{97}$

The constitutional controversy was marked by a major rupture between the federal and Saskatchewan wings of the New Democratic Party. Premier Allan Blakeney of Saskatchewan has incisively criticized his own national leader, Edward J. Broadbent, because of the latter's alliance with the Liberals to dispatch the constitutional package to the Queen. Broadbent, encouraged by such party elders as T. C. Douglas, who for almost two decades (1944-61) was Premier of Saskatchewan, said that the achievement of a charter of rights was a longstanding goal of the party. Blakeney answered that the abolition of the present undemocratic upper chamber was also a historic commitment and that the proposed amending procedure would constitutionalize the Senate's role. It would become an entrenched part of the amending procedure in contrast to the merely customary function it played in sending a Joint Resolution to London. As mentioned above, and probably in part as a result of this debate, the Senate veto was converted into a temporary delaying power.

In the deliberations of the parliamentary committee studying the preliminary draft in December 1980 and January 1981, N.D.P. members pressed successfully for the inclusion of provisions on aboriginal rights for Canada's native peoples, for women's rights, and for nondiscrimination or equality rights on the basis of mental or physical disability. At one point, the federal government was on the verge of trying to enlist Conservative support by inserting a clause sought by the Tories protecting property rights, but reneged on its tentative acceptance of this provision when the left-wing N.D.P., which regarded the proposal as an impediment to its possible nationalization plans should it gain power, threatened to withdraw.

With all four Western provincial governments opposed to the initiative, Trudeau regarded the support of the thirty-two member N.D.P. caucus, twenty-six of whom represented Western ridings, as critical. If he could not broaden the provincial consensus, he would try to expand his parliamentary support by propitiating the federal N.D.P. The Saskatchewan N.D.P., however, was a different case. At this stage, Premier Blakeney found the final package unacceptable for

97. Constitution Act, supra note $16, \S 92 A$. 
three reasons. First, the referendum method of amendment set out in section 46 lent itself too readily to political manipulation, and was available only to the federal government. Second, while section $92 \mathrm{~A}(2)$ conceded the provinces legislative power, subject to federal paramountcy, to make laws in relation to the interprovincial marketing of natural resources, such resources as oil or potash were predominantly sold in international markets and an interprovincial power relative thereto would be of very limited usefulness. Actually, what was needed, again subject to federal paramountcy, was a power over the international marketing of resources, but Ottawa was not ready to concede this. Third, in the wake of threatened Senate opposition, the federal government had conferred a full veto power over future amendments to the unelected Senate, and this was both inappropriate in the context of a new constitution and in contravention of longstanding Cooperative Commonwealth Federation-N.D.P. policy.

With the impasse between the federal and Saskatchewan N.D.P. continuing, four of seven provincially elected Saskatchewan N.D.P. Members of Parliament broke ranks with their federal leader to support Blakeney. Among them were the federal party's constitutional spokesman Lorne Nystrom (Yorkton) who was obliged to vacate that role. The tension between Broadbent and the powerful Saskatchewan wing of the party (in power provincially for thirty of the last thirtyseven years) was at an unprecedented level. The atmosphere in the N.D.P. caucus in Ottawa between the four defectors and their twenty-eight colleagues was said to be frigid.

As a remorseless Trudeau prepared to invoke cloture to preclude further dilatory tactics by the Conservatives so that the Joint Resolution could be sent to London, the eight nonconcurring premiers, now including Blakeney and Buchanan of Nova Scotia, tried to arrive at a last-minute alternative amending formula. Blakeney urged a simpler package consisting of a patriation and an amending formula (without the Charter) which could command a consensus. The participants could then go back to the table to proceed with a charter, if they so wished, and with the difficult unresolved matters of common institutions (e.g., a new upper house and a reconstituted supreme court) and the division of powers. This would be more productive of harmony, and would probably create a more durable constitution, one more generally acceptable to all the units of the federation.

Many of the premiers now preferred the Vancouver to the Victoria amending formula. A difficulty for both Trudeau and Blakeney with the original version of the Vancouver formula was that it had an opting-out provision, requiring seven provinces plus federal concurrence for an amendment, but enabling up to three dissident provinces to opt out if they found the amendment uncongenial. ${ }^{98}$ Opponents of the Vancouver formula charged that this would make the Constitution a veritable patchwork quilt with widely differing provisions applying to different parts of the country.

98. See The Globe and Mail (Toronto), supra note 88 , for the formula accepted by the majority, which is a modified version of the Vancouver formula. 
To meet this objection, in a last-ditch effort to forestall Trudeau's action, the eight dissenting premiers sought to restrictively delimit the opting-out provision. The Winnipeg variation of the Vancouver formula (named for a March 1981 meeting of eight provinces' representatives at Winnipeg) would require the consent of Ottawa and two-thirds (seven) of the provinces having at least 50 percent of the population of Canada. Opting-out would be limited to instances where a successful amendment infringed the legislative or proprietary rights of a province or did "anything to derogate from provincial rights." This latter clause was thought to be less broad than the phrase "affecting provincial rights" in the original Vancouver formula. In addition to Saskatchewan, Nova Scotia and British Columbia were said to be the strongest proponents for tightening up the opting-out provision. The simpler provincial package would not provide for a permanent Senate veto or a referendum..$^{99}$ On April 3, 1981, the eight premiers agreed definitively to a variant of the Vancouver formula, thus tending to refute Trudeau's allegation that they could never agree; his retort was that he could not take them seriously. ${ }^{100}$ The final text of the premiers' amending formula, however, dated April 16, 1981, was the text adopted by Trudeau and nine premiers in the ultimate November Fifth Accord. Trudeau insisted on the deletion of provisions from this formula for the fiscal compensation of provinces which opted out of an amendment (with the sole exception of education and culture) and also on the elimination of provisions concerning the inter-delegation of powers, to which the provinces agreed. 101

The quest for an amending formula and a new constitution by Prime Minister Trudeau must be seen in the perspective of his entire career. The historical record shows that this man who as a young law professor fought against the authoritarian regime of Premier Duplessis has always been attracted to the idea of natural or inalienable rights. He has delighted in reading Plato and Aquinas and has a predilection for universal standards. At the same time he can display great toughness and determination in crises, as evidenced by his invocation of sweeping peacetime emergency powers during the October crisis of 1970, and during the double-digit inflation of 1975. His elitism and arrogance are revealed by some of the statements he made while still a young intellectual about his compatriots:

Historically, French Canadians have not really believed in democracy for themselves; and English Canadians have not really wanted it for others. Such are the foundations upon which our two ethnic groups have absurdly pretended to be building democratic forms of government. No wonder the ensuing structure has turned out to be rather flimsy. ${ }^{102}$

In other words, if the people of Quebec and the substantial majority of provincial premiers, as well as 64 percent of the people of Canada, according to an opinion poll, dislike the process or even some of the substance of the Charter, they must have it anyway because they need it; the Prime Minister and the carefully selected groups appearing before his parliamentary committee know best! Never has there been such elitism in constitution-building in a federal state. In Trudeau's ringing parliamentary defense of his action he scornfully branded the many foes of his

99. Star-Phoenix (Saskatoon), Mar. 28, 1981, at 1, col. 6 .

100. The Globe and Mail (Toronto), Apr. 4, 1981, at 1, col. 2.

101. The Globe and Mail (Toronto), supra note 88 .

102. Trudeau, supra note 24 , at 103. 
unilateral initiative as cowards. ${ }^{103}$ Those who opposed him must be evil. In other states constitution-building is an act of unity and rededication; the recent Canadian process has engendered recriminations and divisiveness. It is bound to increase alienation, especially in the disaffected West, and will add to the growing ranks of separatists in the country. One wonders what moral authority such a constitution will have.

While the Prime Minister is concerned with maintaining his native province in the federation, this concern is not the source of his anxiety about that province. He promised a new constitution even in the event of a "no" vote, but both Lévesque and Liberal leader Claude Ryan firmly reject Trudeau's constitution. In Quebec it is more likely to be seen as an irritant than as a conciliatory gesture. As a leading constitutional scholar has said:

The irony is that 'patriation' of the B.N.A. Act and the insertion of an 'entrenched' bill of rights have become priority issues devised by English Canada and used by a French-Canadian Prime Minister as a response to Quebec demands that ignore these issues. These proposals should, I think, be appraised on their merits and considered as English-Canadian demands whose impact, if any, will be in English Canada. ${ }^{104}$

The record is replete with documentation that past amendments affecting provincial rights have been obtained only subsequent to the securing of provincial consent. The historical foundation of the compact theory has been questioned in both Canada ${ }^{105}$ and the United States, ${ }^{106}$ but that does not reflect the obligatory nature of the theory (described as "fully crystallized" by Liberal Justice Minister Guy Favreau in 1965 ${ }^{107}$ )animating the principal Canadian constitutional actors. Successive compliance by federal-provincial negotiators and governments had by then congealed from usage into convention and arguably into law. The need for unanimity for amendments has been the premise of successive constitutional conferences and was even referred to by Trudeau himself as a necessary precondition in February 1979. In the the words of Trent University political scientist Denis Smith:

The Trudeau government has been cavalier with the contention of unanimity in constitutional change. Through more than a decade, Mr. Trudeau participated in constitutional meetings on the assumption that unanimity is necessary before major constitutional change can proceed. Now the Prime Minister declares that he can ignore the principle on the grounds that unanimity, defined on his terms, is too difficult to achieve. Does Ottawa's failure to gain its objective justify it in declaring the process invalid. ${ }^{108}$ [Emphasis in original]

The tenor of a secret "ministers' eyes only" memorandum, prepared by federal officials on the instruction of the cabinet and leaked by an unknown sympathizer to the Quebec provincial delegation before the September 1980 First Minister's Conference, was disturbing to the provinces. It advised the Prime Minister to

103. The Globe and Mail (Toronto), Mar. 24, 1981, at 1, col. 1.

104. E. MCWhinney, Quebec AND THE Constitution, 1960-1978, at 115 (1979).

105. Rogers, The Compact Theory of Confederation, in Proceedings of THe Canadian Political SciENCE ASSOCIATION 205-30 (1931).

106. The compact theory was first criticized by Daniel Webster in 1833 in the United States Senate.

See MCConNELl, supra note 40, at 121-22.

107. FavreAu, supra note 77 , at 15 .

108. Smith, Napoleon $I V$ in the Making, Macleans, Jan. 19, 1981, at 8 
exploit divisions among the provinces during the deliberations, and to prepare public opinion for unilateral federal action. ${ }^{109}$ There was bad faith, therefore, in the federal position from the very start. ${ }^{110}$ While there is the strongest evidence of an internal convention that consensus is necessary before an amendment is obtained affecting provincial rights, Trudeau's advisers retorted that only Ottawa had standing to present a Joint Address to the Queen seeking an amendment, and it was improper for Britain to go behind such an Address. The guardianship or trusteeship role assigned to Britain on the basis of section 7 of the Statute of Westminster might call an attitude so potentially subversive of federalism into question, but unfortunately the trusteeship principle is regarded by some as basically political and nonbinding. The British might use a positivistic approach, one which would look merely at the words of the Statute 111 without regarding the surrounding historical circumstances, if they considered that a trust role to safeguard provincial jurisdiction would embitter their future relations with Canada. However, if the Canadian courts or the British government were ready to adopt a broader approach, resorting not to the ipsissima verba of the Statute but to the need to preserve the spirit of federalism, the result could be different. Perhaps Wade goes too far in counseling simple patriation; Kershaw's advice to Britain to do nothing until provincial consent was obtained would be better. ${ }^{112}$

Such an initiative by the Canadian government in a federal setting brought into question the principle of the rule of law itself. In rejecting a narrow "Austinian" approach to constitutional questions, the McRuer Report declares:

The primary organizational ideas of a modern state are its fundamental constitutional laws. It is those primary doctrines, principles and procedures that are the focus of obedience; they are supreme, not particular persons in office at particular times. It is fundamental to 'The Rule of Law' that in the end such enduring ideas are supreme and therefore it follows that all officeholders are under the law, none are above it. ${ }^{113}$

The substance of the above quotation applies just as much to binding conventions or the federal principle. Canada's foremost constitutional scholar, Professor W.R. Lederman, Q.C. of Queen's University, has argued cogently that the convention requiring provincial consensus before amending or derogating from the division of powers has now ripened into a rule of law. ${ }^{114}$ It might also be contended that in a federal system the maintenance of the integrity of the system is logically prior to all other rights. If the system disintegrates, can any other rights be secure?

109. See Report to Cabinet on Constitutional Discussions, and the Outlook for the First Ministers' Conference and Beyond, Aug. 30, 1980. The statement at page 55 is of particular interest: "This underlines the importance of the Prime Minister's closing speech which, in addition to making clear the outcome of the negotiations, should pave the way for the implementation phase." It is obvious from this observation that the federal government was determined to go ahead from the start, whatever the issue of the conference.

110. Alleged Memo on Constitution Stuns Premiers, Star-Phoenix (Saskatoon), Aug. 22, 1980, at 1, col. 1.

111. See Wade, supra note 53.

112. See Kershaw Report, supra note 52.

113. 4 Report of the Royal Commission Inquiny into Civil Rights (McRuer Report), 1969 Report No. 2, 148292, in J. Whyte \& W. Lederman, Canadian Constitutional Law: Case, Notes, Materials 1-4 (2d ed. 1977).

114. Lederman, Constitutional Amendment and Canadian Unity, in Special Lectures, Law SOCIETy OF UPPER CANADA 34 (1978). 
Federalism is a very fragile form of government; Trudeau's whole process represented a movement away from federal towards national government.

\section{$\mathrm{V}$ \\ The Supreme Court's Reference Opinion}

On Monday, September 28, 1981, the Supreme Court of Canada rendered its opinion, ${ }^{115}$ severing the important third reference question into two parts. It ruled $6-3^{116}$ on the first branch of the third question that as a matter of constitutional convention it was necessary to obtain provincial consent before making constitutional amendments affecting federal-provincial relations or the rights, privileges, and powers of the provinces. Notwithstanding the foregoing convention, in answer to the second branch of the question, the court held $7-2^{117}$ that as a matter of strict law the federal government had the legal power to present a parliamentary resolution to the Queen requesting, as a final amendment by the British Parliament, that the Canadian Constitution be patriated with a domestic amending formula and a rights charter.

In reply to the first reference question, the court held unanimously that the proposals would derogate from provincial powers; in answer to the second it ruled 6-3118 that there was an unwritten convention that the House of Commons and Senate would not ask Britain to amend the constitution in a manner that would affect provincial powers without provincial consent. Thus, while the federal government had the legal power to present its unilateral proposals to Westminster, such action was unconstitutional in the conventional sense because it had the support of only two provinces, Ontario and New Brunswick. An examination of precedent revealed that the support of two provinces was insufficient. ${ }^{19}$ No amendment affecting provincial rights had ever gone forward with so little support.

The court did not say that provincial unanimity was necessary before a joint resolution could be dispatched to Britain, pursuant to convention, but neither did it define the number of provinces needed to satisfy the conventional requirement. Only Saskatchewan counsel had argued before the supreme court that unanimity was not necessary. The lack of definition in this part of the opinion led the Prime Minister to express puzzlement at the court for invoking a convention without precisely describing its contents. The position of the court appeared to be that it was a judicial body, and that since the conventions arose from a sense of obligation

115. Reference re Amendment of the Constitution of Canada, 125 D.L.R.3d 1 (1981).

116. Id. The Justices in the majority on this point were Martland, Ritchie, Dickson, Beetz, Chouinard, and Lamer. Chief Justice Laskin and Justices Estey and McIntyre dissented.

117. Id. Chief Justice Laskin and Justices Dickson, Beetz, Chouinard, Lamer, Estey, and McIntyre formed the majority on this issue. Justices Martland and Ritchie dissented.

118. Id. Justices Martland, Ritchie, Dickson, Beetz, Chouinard, and Lamer formed the majority on this point. Chief Justice Laskin and Justices Estey and McIntyre dissented.

119. "It is sufficient for the Court to decide that at least a substantial measure of provincial consent is required. . . The situation is one where Ontario and New Brunswick agree with the proposed amendments whereas the eight other provinces oppose it. By no conceivable standard could this situation be thought to pass muster. It clearly does not disclose a sufficient measure of provincial agreement. Nothing more should be said about this." 125 D.L.R.3d, at 36. 
brought about by the reciprocal actions of interested parties in the political arena, those responsible actors should decide upon the required number for themselves. ${ }^{120}$

Hypothetical questions such as those listed above would not be entertained by the United States Supreme Court which has consistently refused to render advisory opinions. Robert G. McCloskey has suggested that responses to such questions would be inconsistent with the separation of powers, powers which are perhaps considered more insulated from each other in a presidential than in a parliamentary system. "Certain ticklish questions of international law were arising in connection with the Neutrality Proclamation of 1793 , and although President Washington wanted the Court's advice in solving them, the Court declined to give him any, arguing that 'advisory opinions' were inconsistent with the judicial function." 121 Referring to the foregoing issue, Richard B. Morris in his 1965 Bacon Lectures at Boston University said that Chief Justice John Jay settled the question of advisory opinions "for all time."122 In Canada, on the other hand, reference questions, inter alia, on "the constitutionality or interpretation of any federal or provincial legislation," 123 and on "the powers of the Parliament of Canada, or of the legislatures of the provinces, or of the respective governments thereof, whether or not the particular power in question has been or is proposed to be exercised," 124 may be transmitted by the Governor in Council to the Supreme Court of Canada pursuant to the Supreme Court Act. Such sensitive issues as the constitutional validity of Prime Minister R.B. Bennett's "New Deal" social welfare measures (based in part on President Roosevelt's New Deal) ${ }^{125}$ or the validity of the federal government's sweeping 1975 wage and price controls ${ }^{126}$ have been transmitted to the court for constitutional analysis under this provision. References like these have, in effect, made the court an umpire between political adversaries in the Canadian federal system in instances where there was no actual case or controversy ${ }^{127}$ in the American sense.

The supreme court decision appeared to be a spur to further political negotiations because it gave something to each of the contending parties. The decision separated the legal from the political issue, but simultaneously suggested that fully constitutional action could be brought about only by the cooperative efforts of the adverse parties. While the court rejected the argument of Professor Lederman that the applicable convention requiring prior provincial consent had acquired the force of law, ${ }^{128}$ the court agreed in reply to the third question that the convention

120. Reference re Amendment of the Constitution of Canada, 125 D.L.R.3d 1 (1981).

121. R. McCloskey, The American Supreme Court 32 (1960).

122. R. MORRIS, JOHN JAY, THE NATION AND THE COURT 45-46 (1967).

123. The Supreme Court Act, Can. Rev. STAT. c. S-19, 55(1)(b) (1970).

124. Id. $\S 55(1)(\mathrm{d})$.

125. See McConnell, The Judicial Review of Prime Minister Bennett's "New Deal", 6 OsgoOde Hall L.J. 53 (1968); McConnell, Some Comparisons of the Roosevelt and Bennett "New Deals", 9 OScOODE HALL L.J. 221 (1971).

126. Reference re Anti-Inflation Act, 68 D.L.R.3d 452 (1976).

127. Cf. U.S. ConST. art. III, $\S 2$, cl. 1.

128. "The leap [by Lederman] from convention to law is explained almost as if there was a common law of constitutional law, but originating in political practice. That is simply not so. What is desirable as a political limitation does not translate into a legal limitation, without expression in imperative constitutional text or statute." 125 D.L.R.3d at 26. 
existed at least as a political limitation on the action of the parties.

In Seoul, South Korea, before leaving for a Commonwealth prime ministers' conference in Australia, Trudeau at first appeared to be conciliatory to the provinces, but placed the onus directly upon the eight dissident premiers to come up with new proposals. ${ }^{129}$ Ottawa Justice Minister Chrétien seemed less accommodating. He emphasized that part of the opinion describing the federal government's proposed resolution as legally permissible and tended to minimize the holding on convention. ${ }^{130}$ Premier Bill Bennett of British Columbia, the chairman of the premiers opposing the federal initiative, argued that the opinion should be considered as a whole and that meaningful new federal-provincial negotiations should be undertaken. ${ }^{131}$

British Prime Minister Margaret Thatcher, attending the same conference in Melbourne, pledged to introduce a resolution to amend the Canadian Constitution for the last time. She would give no assurances, however, as to the time required for its passage. ${ }^{132} \mathrm{Her}$ uncertainty on this score was perhaps intensified by her awareness of a group of British parliamentary backbenchers who had seriously doubted the propriety of Ottawa's unilateral action, and whose opposition was strengthened by the supreme court's decision. In a telegram, Sir Bernard Braine, former British State Undersecretary for Commonwealth Relations urged Thatcher to impress upon Trudeau the importance of reaching a negotiated settlement. ${ }^{133}$ He pointed out that because of the respect with which convention is held in Britain, a country with an unwritten constitution, if the Canadian Parliament were to take unilateral action, the lengthy portion of the court's opinion dealing with the need for provincial consent to amendments would carry a great deal of weight.

\section{VI}

\section{Conclusions}

An influential factor in Trudeau's decision to compromise with the nine English-speaking premiers was the Supreme Court of Canada's decision that a unilateral constitutional package supported only by the federal Parliament, Ontario and New Brunswick would clearly violate convention and would thereby be unconstitutional. "Some things were given up," said Trudeau, "in order to constitutionalize the amending process. The things I gave up_-some of them made me sad."134 Had he not given them up, the Prime Minister would have been left in the position of insisting that the British Parliament conform to the external convention of passing the Canadian Joint Resolution automatically, while he himself breached the domestic convention requiring substantial provincial consent. A related factor in his decision to compromise was the doubt that existed about whether the British

129. The Globe and Mail (Toronto), Sept. 29, 1981, $\S \mathrm{D}$, at 1, col. 2.

130. Id. at col. 4.

131. Id. at col. 1.

132. The Globe and Mail (Toronto), Oct. 6, 1981, § B, at 1, col. 1.

133. The Leader Post (Regina) Oct. 1, 1981, at 10, col. 3.

134. The Globe and Mail (Toronto), Nov. 19, 1981, at 1, col. 1. 
Parliament would enact a Joint Resolution presented unilaterally after the supreme court's decision especially in view of adverse comments by a majority of the judges on such a procedure. That decision had been anticipated in the interest at Westminster.

The most extensive surrender by the Prime Minister involved the insertion of the legislative supremacy (the notwithstanding) clause in the new section 33, enabling either Parliament or the provincial legislatures to override fundamental freedoms as set out in section 2, or the legal or equality rights enumerated in sections 7 to $15 .^{135}$ Originally, the override was to apply as well to the guarantee of equality to males and females in section 28 , but after extensive criticism this section was not made subject to the clause. ${ }^{136}$ This resulted in the odd situation that a legislature could declare that its laws would operate notwithstanding the ban on discrimination on the basis of sex in section 15, but subject at the same time, to the mandate of male and female equality in section 28. Presumably, if discrimination resulted through the use of a notwithstanding clause in section 15 , the discrimination would have to be imposed equally by virtue of section 28 . It might be suggested that this is a rather curious consequence of a charter meant to guarantee rights.

There does not seem to be any limitation on the use of the overriding power. In the case of the fundamental freedoms in section 2 (for instance, the freedoms of religion, opinion, expression, press, peaceful assembly and association), Parliament or the legislatures may derogate from or nullify such liberties at will-no matter how arbitrary or capricious their legislation may seem. Surely, there is something wrong with the conferment of an express legislative power in a bill of rights to set its most precious freedoms aside by mere legislative fiat. By such a provision a person may freely worship as long as he does not do so according to the tenets of a proscribed sect; he may freely speak as long as he does not advocate unwanted political doctrines; he may publish newspapers and books only on sufferance of the state which may exercise prior restraint on publication at will; he may peacefully assemble or associate with others but only on conditions prescribed by the state.

It may be said that the notwithstanding clause in section 33 will be used only infrequently - that public opinion will serve as a powerful deterrent to its use. It has been pointed out for example, that an analogous clause in section 2 of the 1960 Canadian Bill of Rights was used only once in over twenty years, during the F.L.Q. terrorist crisis in Quebec in October 1970. ${ }^{137}$ However, the clause in section 33(1) can be used not only by Parliament (as in the case of Diefenbaker's 1960 legislation) but by eleven governments, both provincial and federal, each with differing attitudes, legislative programs, and value systems. Public opinion has never been a very powerful support of civil liberties in Canada. Some of the legislatures controlled by Canadian governments in the past have made the advocacy of sub-

135. The Globe and Mail (Toronto), Nov. 19, 1981, at 2, col. 6; id. at 12, col. 4. See Constitution Act, supra note $16, \S 33$. $\S 28$.

136. The Globe and Mail (Toronto), Nov. 24, 1981, at 1, col. 3; see Constitution Act, supra note 16, at

137. Hay, $A$ Bird in the Hand at the Flea Market, Macleans, Nov. 16, 1981, at 34; see Public Order (Temporary Measures) Act, Can. Stat. 1970-71-72 c. 2 \$12(1) (Expiration date Apr. 30, 1971). 
versive ideas criminal or subject to penalty; ${ }^{138}$ have given a provincial attorneygeneral the right to define "bolshevism" (without any guidelines), and to padlock premises used for its dissemination; ${ }^{139}$ have incarcerated innocent Japanese without legal process in internment camps in wartime; ${ }^{140}$ and have prohibited the acquisition by communal religious sects of additional lands for settlement purposes. ${ }^{141}$

It will be in instances involving unpopular groups or causes that the new Charter will really be tested. In my opinion, the overriding power will be used and may be used frequently. The provisions of the Charter, it should be recalled, are much more extensive than those in Diefenbaker's Canadian Bill of Rights, and apply to both orders of government. A likely area for federal legislative intervention would be in the area of legal rights (sections 7 to 14) which, if interpreted broadly by the courts might be criticized as hampering police powers and making the detection and prosecution of crime more difficult. This is probably an area where public opinion would encourage restriction, rather than expansion, of civil liberties in the interest of law enforcement.

If one postulated power to override at the disposal of state governments in the United States, it would make the first (fundamental freedoms), the fourth, fifth and sixth (legal rights), and the fourteenth (equality rights) amendments contingent on the will of the local legislatures. Clothed with such a power, would northern abolitionist state governments have hesitated to declare the Dred Scott decision ${ }^{142}$ inoperative within their boundaries? Would some state governments not have rescinded the order to desegregate their public school systems made by Chief Justice Warren in Brown v. Board of Education? ${ }^{143}$ Would Tennessee, given such a power, have peacefully acquiesced to the mandate of Baker $v$. Carr ${ }^{144}$ to reapportion its legislative districts? It is my guess that in all of these cases, and in similar Canadian cases, such a supremacy clause, if available, would have been used.

The very existence of such a power will probably have a cautionary effect on Canadian courts making decisions in civil liberties areas. Judges who may want to maintain the credibility of the bench will not readily make decisions on the frontiers of civil liberties which can so easily be offset by legislatures.

One of the leading authorities on the Canadian Constitution and a close ally of Trudeau in the battle against the provinces, former Senator Eugene Forsey, ${ }^{145}$ has

138. W. TARnOPOlsky, THE Canadian Bill of Rights 327 (2d rev. ed. 1975).

139. Id. at 39; see Act Respecting Communistic Propaganda, Que. Stat. c. 11 (1937), as amended by QUE. REV. STAT. c. 52 (1941), which was found unconstitutional after two decades of operation in Switzman v. Elbling, 7 D.L.R.2d 337 (1957).

140. See TAR NOPOLSKY, supra note 138; Co-operative Committee on Japanese-Canadians v. Attorney General of Can., [1947] A.C. 87 (J.C.P.C.).

141. See TARNOPOLSKy, supra note 138, at 71-72; Walter v. Attorney General of Alta., 3 D.L.R.3d 1 (1969).

142. Dred Scott v. Sandford, 60 U.S. (19 How.) 393 (1857).

143. Brown v. Board of Education, 347 U.S. 483 (1954).

144. 369 U.S. 186 (1962).

145. Senator Forsey is the author, inter alia, of two leading works on the Canadian Constitution: THE Royal Power of Dissolution of Parliament in the British Commonwealth (1943) (concerning the King-Byng controversy of 1926) and FreEdOM AND Order: COllected Essays (1974). 
asserted that by the November Fifth Accord, the provinces "have shot [the charter] full of holes, great big, gaping holes .... [W] hat the charter rightly calls 'Fundamental Freedoms' . . . are put at the mercy of [ten] provincial legislatures which can override them at will."146 The same, he adds, is true of legal and equality rights. Senator Forsey is strangely silent about the fact that in addition to the provinces, Parliament can also override the mentioned rights. Other than for a kind of perverse symmetry, there was no need for Trudeau to claim an overriding power for Parliament. Should he not have set an example to the provinces by accepting the Charter unreservedly, irrespective of the attitude of the provinces, as was his purpose in Bill C- $60,{ }^{147}$ the predecessor to the present Charter? Given the existence of such an overriding power, it may be asked in what sense the mentioned rights and freedoms are entrenched?

\section{A. The Isolation of Quebec}

When the nine English-speaking premiers and the Prime Minister arrived at their compromise, they contended that Premier Lévesque had surrendered Quebec's veto in April 1981, when he accepted the Vancouver formula. ${ }^{148}$ According to that formula, ${ }^{149}$ no distinction was made between provinces with respect to the securing of future amendments. No province possessed special status (as did Quebec and Ontario under the Victoria formula). What was required to make an amendment was simply the consent of Parliament plus any seven (or twothirds) of the provinces having an aggregate of 50 percent of the country's population.

There was an important proviso, however, in the original premiers' formula allowing up to three nonconcurring provinces to opt out of any amendments and receive fiscal compensation. ${ }^{150}$ The November Fifth Accord limits compensation more narrowly to instances affecting education or culture. ${ }^{151}$ For Lévesque the unrestricted opting-out provision was an alternative to the provincial veto. Whatever action the other provinces might take, Quebec would not be adversely affected if it failed to concur and opted out.

Lévesque and spokesmen for native groups complained alike about the November Fifth Accord. In arriving at a consensus which disregarded their special status, they contended, the leaders of the ten governments with English-speaking or non-native majorities had deprived them of their historic right to participate in constitutional renewal. It was easier for Premier Lévesque to make the argument as Premier of Quebec than as leader of the separatist Parti Québecois. As Premier he could argue that he spoke for one of two "nations"; as party leader he led a movement committed to ultimate political independence and his credibility would

146. The Globe and Mail (Toronto), Nov. 21, 1981, at 7, col. 1.

147. Government of Canada, The Constitutional Amendment Bill $\$ \$ 131(1)$, (3) (June 1978).

148. Anderson, supra note 2, at 29-30.

149. See the revised text of the Constitution Act, supra note $3, \S 37$ (renumbered $\S 38$ in the Constitution Act, supra note 16).

150. See Amending Formula for the Constitution of Canada $\S 3$ (Apr. 16, 1981).

151. Constitution Act, supra note $16, \S 40$. 
be compromised, at least among party members, if he became, so to speak, a new "Father of Canadian Confederation."

The "two nation" doctrine has important consequences for Canadian constitutional theory. It signifies that in addition to being ten federated provinces and a central government in Ottawa, Canada is comprised of two distinctive cultural and linguistic entities, the conjunction of whose wills is needed to achieve important constitutional change. Carried to its strict conclusion, it might posit two "national" panels on a reconstituted Supreme Court of Canada, or division of the Senate or federal cabinet into two parts that must reach agreement in order to act, at least on those matters affecting the two "cultural communities."

This form of constitutional dualism relates especially to legal changes involving culture, language and education, because the very survival of a vulnerable cultural minority in a federation depends on local jurisdiction in such areas. It would also embrace any fundamental change in the Constitution as regulating the future relationships between the partners. As Professor Edwin R. Black has said:

$[t]$ he constitution in a federation must be of major concern to a beleaguered racial minority. If [the constitution] is too easily changed, [the minority] may be defenseless. But if both majority and minority races [had been] equal in status and loyalty, and if both had been parties to an agreement on the terms of union, then it follow[s] that those terms could not lightly be altered without the assent of both groups. ${ }^{152}$

Such constitutional dualism has received many expressions. Of particular relevance to the November Fifth Accord is the form Premier Duplessis gave to it in his government's 1945 throne speech: "The Government consider[s] that it belongs neither to the majority of the provinces nor the Ottawa Government to bring about changes in the Canadian Constitution. I firmly believe that the British North America Act is a pact of honor between the two great races; my government intends to respect it, it exacts that respect."153 The Tremblay Report of 1956, authorized by the Quebec government to examine constitutional problems-especially those arising from the centralization growing out of the Second World War-declared:

By reason of its history, as well as the cultural character of its population, Quebec is not a province like the others, whatever might be said to the contrary. It speaks in the name of one of the two ethnic groups which founded [the] Confederation, as one of the two partners who officially have the right to live and expand in this country. It is the only one able to represent one of these two partners. ${ }^{154}$

In his terms of reference to the 1963 Royal Commission on Bilingualism and Biculturalism, federal Prime Minister Lester B. Pearson charged the commissioners to conduct their inquiry on the basis of "equal partnership between two founding races." 155 In the Quiet Revolution of the 1960s, when Quebec was undergoing dramatic social and educational reform, Premier Daniel Johnson declared: "Because of the disparity in numbers between the two nations, . . . both in Canada as a whole and in each of the provinces, Canada can only be binational

152. E. Black, Divided Loyalties 188 (1975).

153. Id. [Emphasis added]

154. I Report OF THE ROYal COMmission OF Inquiry OF Constitutional Problems (TRemBLAY REPORT) 182 (1956).

155. Royal Commission on Bilingualism and Biculturalism, supra note 6. 
if it is structured in such a way as to guarantee and effectively protect the legal equality of the two elements." 156 Johnson would have entirely dispensed with the mechanism of a final amendment from the British Parliament. He urged instead that each "nation" should stipulate and define its constitutional objectives. These objectives could then be set out in a new Canadian constitution by a constituent assembly, which would take pains to ensure the "juridical equality of the two nations."157

Because Canada has never possessed a domestic amending formula, however, the declarations by successive Quebec premiers and public lawyers have always lacked a specific focus in positive law; they rest instead on historical and philosophical premises. That is not to say that such understandings are not important. Federalism is a system in which regions differ culturally and economically; its viability depends upon a common sentiment of nationality. Statements by Quebec public figures demonstrate that the psychological or the spiritual dimension of Canadian nationality rest on a two nation theory. If $Q$ uebec is simply a province like any other, assimilation should result, as with the French-Canadian immigrants in Maine and Louisiana.

When the leaders of the English-speaking provinces and Prime Minister Trudeau reached a constitutional consensus which omitted Quebec they were asserting, implicitly and explicitly, that despite the two nation theory, a new Canadian constitution could be made without the participation of that province. Admittedly, it would have been difficult to make a definitive constitutional pact with a Quebec separatist government. Premier Lévesque had shown, however, that he was ready to move on a smaller package in April 1981.158 The alternatives were to make a more modest bargain that would include Quebec, or to wait until the next provincial election in anticipation that Lévesque might be defeated and replaced by a provincial leader committed to continued federalism. Such an election might not be held, however, until 1986 and the others were not willing to wait. Having rejected the idea of a smaller package involving patriation and the Vancouver amending formula, but not the Charter with its incendiary language rights, the ten "Accord" governments boldly gambled that some means would be found to contain rising Quebec nationalism within the federation. Perhaps, in the end, the gamble will succeed.

Temporarily outflanked by Trudeau and the nine premiers, Lévesque commenced court action to determine if the consensus for change, postulated by the supreme court in its opinion of September 28, necessarily included Quebec. Trudeau, however, refused to interrupt the constitutional process pending the outcome. In support of his position Trudeau cited the court's holding that where convention was involved it was the political actors, rather than the courts, whose judgments were crucial, and pointed to Lévesque's surrender of the veto. ${ }^{159}$

A U.S. parallel of the two nation principle was John C. Calhoun's doctrine of

156. D. Johnson, EGalite OU INDEPENDANCE 115-16 (1965) (translation by author).

157. BLACK, supra note 152 , at 194.

158. See The Globe and Mail (Toronto), Apr. 4, 1981, at 1, col. 2; id. Apr. 17, 1981, at 1, col. 2.

159. The Globe and Mail (Toronto), Dec. 5, 1981, at 1, col. 3. 
the concurrent majority. According to this theory, each major interest in the nation brandished a veto power. As an illustration he cited a community of twenty-four members divided into a major interest of thirteen and a minor interest of eleven. If only an absolute majority were needed the thirteen would invariably prevail. ${ }^{160}$ Under a concurrent system, however, a majority of each interest (i.e., seven of the majority and six of the minority) would be required for lawmaking. A double majority would be substituted for an absolute majority. Calhoun regarded the North and the South as the two major interests in the United States; ${ }^{161}$ Lévesque regards Quebec, the homeland of French-speaking Canadians, and the ten other governments, representing English-speaking majorities, as the concurrent powers in Canada. Where vital interests, or basic constitutional reform, is in question a double majority is essential; presumably regardless of whether the forum is a First Ministers' Conference or whether joint action by the federal Parliament and the Quebec National Assembly is contemplated.

It was in this context that, on November 25, Premier Lévesque's government adopted an order-in-council exercising what he termed his province's historic veto to block the constitutional resolution. ${ }^{162}$ Lévesque contended that he was using the same veto power exercised in 1971 by Premier Bourassa of Quebec to reject the Victoria formula at that time, ${ }^{163}$ Quebec's veto then being accepted by all the other governments. He also argued that he had not relinquished the veto in the sense contended by the ten in the April Accord formula, since his government had agreed to the proposal only on condition that a right of opting-out with full financial compensation was included; a condition that was not met. ${ }^{164}$

Echoing Calhoun, a week before Lévesque's dramatic gesture, Mr. Justice Thomas R. Berger of the British Columbia Supreme Court said that Canadians should decide whether they accepted the principle of duality or not:

The Parliament of Canada is and always will be predominantly English-speaking. Parliament has a veto. The National Assembly is, and always will be, predominantly Frenchspeaking. It is the only government in North America in which francophones are a majority. Representing as is does, the heartland of French Canada, it should have a veto. This is essential if we accept the principle of duality. ${ }^{165}$

Mr. Justice Berger also criticized the temporary deletion of section 35 on native rights. "If the new Constitution and the Charter acknowledge the claims of the two founding peoples, then how can they refuse to acknowledge the place of native people?" 166 The native people, it should be added, do not consider themselves an ethnic minority, but a founding people in their own right. ${ }^{167}$

Berger also suggested that since the settlement of native claims was the historic duty of Ottawa, the federal government should compensate the provinces when-

160. G. Capers, John C. Calhoun_Opportunist: A Reappraisal 245-46 (1960).

161. Id.

162. The Globe and Mail (Toronto), Nov. 26, 1981, at 1, col. 2.

163. Id.

164. See id. at 2, col. 1; Amending Formula for the Constitution of Canada, supra note 150.

165. The Globe and Mail (Toronto), Nov. 18, 1981, at 7, col. 3.

166. Id. at col. 5 .

167. D. Opekokew, The First Nations: Indian Government and the Canadian ContederaTION $1-3$ (1980). 
ever lands under provincial jurisdiction were transferred to native peoples. ${ }^{168}$ An irate Prime Minister Trudeau rejected this suggestion, saying, "I just regard that as the judiciary getting mixed into politics ... I hope the judges will do something about it."169 Chief Justice Nathan Nemetz of the British Columbia Court of Appeal, at whose discretion disciplinary measures would be instituted, had "no comment at this time."170

\section{B. The Uneasiness of Native Peoples}

The Indian, Inuit and Métis peoples regard themselves as nations similar to Quebec, entitled to self-government within the federation. As a Saskatchewan lawyer of Cree origin said:

The Indian peoples' perception of their status is analogous to Newfoundland before it entered Confederation. Our people entered into a Protectorate or trust relationship with the Crown in her [sic] capacity as the Queen of Great Britain. That trust relationship is but a stepping stone in our political, social, cultural and economic development as the original peoples and partners in Confederation. ${ }^{171}$

Many Canadian Indians prize the link with the British Crown over the link with Ottawa whom they perceive as insensitive to their claims of nationhood. Some are taking legal action in Britain to determine whether the British have a continuing responsibility for the protection of Indian rights in Canada. ${ }^{172}$ The Kershaw Committee, however, found that "all treaty obligations to native peoples have passed to the Government of Canada."173 In an effort to achieve fuller participation in Canadian government, some Indians have suggested that an Indian "province" of somewhat diffuse nature be created from among the scattered enclaves of Indian peoples in Canada. "The procedures established when Newfoundland was admitted would be followed with the necessary establishment of the legislature and federal representation in the main institutions."174 The Métis, or persons of mixed Indian-white ancestry, who number some 700,000 of the country's 1.3 million natives, ${ }^{175}$ desire "some tangible recognition that native people were the original inhabitants of this country and that, from the start, they played a vital and indispensable role in founding and shaping its development."176 Such recognition might take the form of constitutional special status providing the opportunity "for native groups, in their various regions, to exercise their rights of self-determination as indigenous peoples within the framework of Confederation."177 Similarly, in 1976 and again in 1979, the Inuit Tapirisat of Canada, representing some 15,000 Canadian Inuit, or "Eskimos," stated their aspiration for self-determination. It is their hope that within the Northwest Territories, in the area north of the treeline

168. The Globe and Mail (Toronto), supra note 165, at 7, col. 5.

169. The Globe and Mail (Toronto), Nov. 26, 1981, at 3, col. 4 .

170. Id.

171. OPEKOKEW, supra note 167 , at 46.

172. The Leader Post (Regina), Nov. 25, 1981, § B, at 12, col. 1.

173. The Globe and Mail (Toronto), Jan. 31, 1981, at 15, col. 1.

174. OPEKOKEW, supra note 167 , at 47.

175. Anderson, The Unfonished Charter, MaCleans, Nov. 30, 1981, at 26-27.

176. H. Daniels, We Are the New Nation 10 (1979).

177. Id. at 12. 
where there is an Inuit majority, they might achieve "full provincial status over a period of [ten] to [fifteen] years."178 Faced with a powerful separatist movement in Quebec, the federal government has been reluctant to encourage what some have regarded to be the quasi-separatist aims of native organizations elsewhere, which seemed to betoken, even if only in a symbolic sense, further fragmentation in the body politic. However, as was mentioned above, the native peoples have generally regarded Ottawa as distant and insensitive, and as making glacially slow progress towards complying with their wishes for more self-government.

After some hesitation, many Indian and Métis groups, but not the Inuit, rejected what they considered to be the too imprecise acknowledgment in section 35 of the Charter of their aboriginal and treaty rights. This provision was inserted early in 1981 but was removed temporarily in November as part of Trudeau's Accord with the premiers. As a concession to the provinces, according to Maclean's, "Trudeau agreed to drop the Charter clause offering aboriginal and treaty rights ... . Behind the federal move lay and [sic] lingering bitterness felt by Chrétien and other ministers that native groups had continued to lobby against the Charter even with the rights provision on grounds that it was inadequate."179 After much protest by native groups, however, section 35 was restored.

Nobody could accurately have predicted the ultimate November compromise which has given Canada a Constitution with some truly bizarre features. Partly because Prime Minister Trudeau created a false sense of urgency by setting successive deadlines for agreement, compromises were made which should not have been made. Civil libertarians will certainly ponder the power conferred in section 33 upon Parliament and the provinces to override, inter alia, fundamental freedoms. The result is neither the effectuation of British concept supremacy of Parliament, for there has been a substantial shift of decision-making authority to the courts, nor the firmer entrenchment of the guaranteed rights similar to those in the United States Bill of Rights, since the legislative supremacy clause in section 33 signifies that in the area of basic rights the decision of the courts can be overridden. Rights can be overridden by ordinary statute of eleven governments in Canada; whereas in the United States, controversial decisions concerning the prohibition of prayers in public schools, ${ }^{180}$ or the right to abortion in the first trimester of pregnancy ${ }^{181}$ attest that only a constitutional amendment can effect change. Opponents of both the foregoing decisions in the United States strove to mobilize public opinion to achieve the difficult consensus required to obtain a constitutional amendment. Depending upon characterization in Canada, Parliament or the legislatures could do the job. If the purpose of the Charter was to insulate rights and freedoms from a political process that is often insensitive to minority rights, the result is a sadly disillusioning one. Depending upon the frequency of use of the override, it could produce a checkerboard Canada.

178. Report of the Special Representative, Constitutional DeVelopment in the NoRThWEST TER RITORIES 20 (Jan. 1980).

179. Hay, supra note 137.

180. Engel v. Vitale, 370 U.S. 421 (1962).

181. Roe v. Wade, 410 U.S. 113 (1973). 
Most serious in its implications for future Canadian federalism is the isolation of the Province of Quebec, with its distinctive language and culture, in the ultimate patriation process. Section 23 of the Charter, entrenching-where numbers warrant-minority English-language education rights, was strongly opposed by the Quebec government. In the past, Quebec has been more generous to its linguistic minority than have the English-speaking provinces. However, the province desired to impose some controls over access to anglophone education (for example, in the case of out-of-province anglophones moving to Quebec) which section 23 will render impossible. Fearing assimilation on a continent where francophones are vastly outnumbered, the Québecois perceive a serious erosion of their linguistic and educational jurisdiction by the new provision.

In addition, after a temporary reversal of position by Lévesque, both he and Liberal leader Claude Ryan have decried the loss of the Quebec veto. In conformity with Lévesque's original proposal, Senator Duff Roblin (Premier of Manitoba, 1958-67) suggested that fiscal compensation be given in all cases of opting-out under new amendments-rather than just in education and culture-as compensation for the loss of the Quebec vote. ${ }^{182}$ A consequence of the lack of general compensation might be that Quebec would systematically oppose future amendments, making the minimum 50 percent aggregate population requirement more difficult to achieve. Every future constitutional amendment obtained without Quebec support would be a reminder to the Québecois and others that the province did not endorse the Constitution initially. Provincial nationalists would perceive that nationhood and veto (or in Calhoun's terms, sectionalism and concurrent majority) went together, and that the logical alternative to the loss of the veto was independence. Accordingly, the achievement of a new Canadian Constitution at the expense of isolating Quebec may prove to be a pyrrhic victory. Given the bitterness of the preceding year, the agreement to patriate by ten heads of government was a substantial accomplishment, but much work remains to be done to keep Quebec in the Confederation.

The dimensions of the task became apparent at a convention of the separatist Parti Québecois in Montreal taking place at the same time as the final parliamentary debate on patriation. To the great chagrin of Premier Lévesque, delegates reacted angrily to patriation without Quebec's consent by endorsing outright independence. Party policy had formerly been to obtain sovereignty but with economic association with a reconstituted English-Canada. ${ }^{183}$ Lévesque feared that this more radical "independantiste" position might isolate the Parti Québecois from moderate opinion in the province, and threatened to resign as party president (but not as premier) in protest against this rank-and-file resolution. He saw the resolution as playing directly into Trudeau's hands. The extremism thus inspired would create an equivalent reaction (in Trudeau's terms, a counter-weight) among moderates, perhaps facilitating a return to power by the provincial Liberals. In the long run, however, for Canadian nationalists the danger was that the virtually

182. The Globe and Mail (Toronto), Dec. 4, 1981, at 8, col. 2.

183. The Globe and Mail (Toronto), Dec. 7, 1981, at 1, col. 1. 
irreversible results of the November Fifth Accord would enhance the separatist cause in Quebec. 